\title{
PENGARUH PPH 21 TERHADAP PENERIMAAN PADA KPP MAKASSAR SELATAN
}

\author{
Della Fadhilatunisa ${ }^{1}$ Amran Arsi Cahyani ${ }^{2}$
}

Universitas Muhammadiyah Makassar

e-mail: della.fadhilatunisa@unismuh.ac.id

\begin{abstract}
This research was conducted to illustrate the extent of the influence of income tax acceptance of article 21 on tax revenues at Makassar's primary tax Service office. The method used in this research is a descriptive method with a quantitative approach. The research was conducted at Makassar South's primary tax office with methods of data collection in the form of document studies and field studies. Data analysis is expressed in the form of information that is developed with other data to obtain the clarity between variables so that the conclusion is withdrawn received or rejected hypothesis. The results showed that the results of the test that PPH article 21 have an effect on tax revenues at the primary tax office of the South Makassar.
\end{abstract}

Key words: Pengaruh, PPH article 21, Tax receipt

\begin{abstract}
Abstrak
Penelitian ini dilakukan untuk menggambarkan tentang sejauh mana pengaruh penerimaan pajak penghasilan pasal 21 terhadap penerimaan pajak pada Kantor Pelayanan Pajak Pratama Makassar Selatan. Metode yang digunakan dalam penelitian ini adalah metode deskriptif dengan pendekatan kuantitatif. Penelitian ini dilakukan pada Kantor Pelayana Pajak Pratama Makassar Selatan dengan metode pengumpulan data berupa studi dokumen dan studi lapangan. Analisa data dinyatakan dalam bentuk uraian informasi yang dikembangkan dengan data lainnya untuk mendapatkan kejelasan antar variable sehingga ditarik kesimpulan hipotesis diterima atau ditolak. Hasil penelitian menunjukkan bahwa hasil pengujian bahwa PPH Pasal 21 berpengaruh terhadap penerimaan pajak pada Kantor Pelayana Pajak Pratama Mkassar Selatan.
\end{abstract}

Kata Kunci: Pengaruh, PPH Pasal 21, Penerimaan Pajak 


\section{PENDAHULUAN}

Pembangunan nasional tentu akan membutuhkan dana yang tidak sedikit dalam menjalankan kegiatan pelaksanaannya. Terdapat dua sumber dana dalam melaksanakan pembangunan nasional, yaitu sumber pendanaan yang bersumber dari pajak dan non pajak. Namun sektor pajak merupakan sumber penerimaan utama sekaligus menjadi yang paling penting dalam menopang pembiayaan pembangunan yang bersumber dari dalam negeri. Peranan dan kontribusi pajak terhadap penerimaan negara dalam beberapa tahun terakhir semakin tinggi pasca era eforia bonanza minyak dan gas bumi yang tadinya mendominir penerimaan APBN namun belakangan dominasi itu semakin mengundur dalam tataran makro perekonomian negara.

Kontribusi pajak tersebut semakin diperhitungkan sebagai tulang punggung sumber pembiayaan nasioanal untuk mensukseskan program-program pembangunan yang secara gradual akan meningkatkan pertumbuhan ekonomi serta kesejahteraan bangsa dan masyarakat pada umumnya. Realisasi penerimaan pajak sesuai target APBN, atau lebih terakhir kalinya terjadi pada 2008. Namun sejak tahun 2009 hingga 2016 penerimaan pajak sering kali di bawah target yang telah ditetapkan. Salah satu faktor penyebab penerimaan pajak yang sulit tercapai yaitu kepatuhan wajib pajak yang rendah itu dibuktikan karena perilaku wajib pajak yang menolak membayar pajak karena ketidakpuasan masyarakat atas pelayanan dan mekanisme pajak. Ketentuan umum dan tata cara peraturan perpajakan telah diatur dalam Undang-undang, tak terkecuali mengenai Pajak Penghasilan Pasal 21.

Sejalan dengan pendapatan pajak lainnya adalah Pajak Penghasilan (PPh) Pasal 21 merupakan salah satu pajak yang paling sering berhubungan langsung dengan masyarakat, khususnya para pegawai. PPh Pasal 21 adalah pajak pajak atas penghasilan berupa gaji, upah, honorarium, tunjangan, dan pembayaran lain dengan nama bentuk apapun sehubungan dengan pekerjaan atau jabatan, jasa dan kegiatan yang dilakukan oleh orang pribadi. Berdasarkan uraian dari latar belakang diatas maka permasalahan yang dibahas dalam penelitian ini adalah Apakah PPh Pasal 21 berpengaruh secara parsial terhadap penerimaan pajak pada Kantor Pelayanan Pajak Pratama Makassar Selatan.

\section{TINJUAN PUSTAKA}

\section{Pajak}

Menurut Rochmat Soemitro (2012) Pajak adalah iuran rakyat kepada kas negara berdasarkan undang-undang (yang dapat dipaksakan) dengan tiada mendapat jasa imbalan (kontraprestasi) yang langsung dapat ditujukan dan yang digunakan untuk membayar pengeluaran umum. Sedangkan Menurut Adriani (2007) Pajak adalah iuaran kepada negara (yang dapat dipaksakan) yang terhutang oleh wajib pajak membayarnya menurut peraturan-peraturan, dengan tidak mendapat prestasi kembali, yang langsung dapat ditunjuk, yang gunanya adalah membiayai pengeluaran umum negara.

\section{Pajak Penghasilan}

Undang-undang Pajak Penghasilan ( $\mathrm{PPh}$ ) mengatur pengenaan pajak penghasilan terhadap subjek pajak berkenaan dengan penghasilan yang diterima atau diperoleh dalam tahun pajak. Subjek pajak tersebut dikenai pajak apabila menerima atau memperoleh penghasilan. Wajib pajak dikenai pajak atas penghasilan yang diterima atau diperolehnya selama satu tahun pajak atau dapat pula dikenai pajak untuk penghasilan dalam bagian tahun pajak apabila kewajiban pajak subjektifnya dimulai atau berakhir dalam tahun pajak (Mardiasmo, 2011).

\section{Pajak Penghasilan (PPh 21)}

Menurut Mardiasmo (2011) "Pajak penghasilan pasal 21 adalah pajak atas penghasilan berupa gaji, upah, honorium, tunjangan, dan pembayaran lain dengan nama dan bentuk apa pun sehubungan dengan pekerjaan atau jabatan, jasa, dan kegiatan yang dilakukan oleh orang pribadi”. Menurut Resmi (2009) "Pajak penghasilan pasal 21 adalah pajak atas penghasilan berupa gaji, upah, honorium, tunjangan, dan pembayaran lain dengan nama dan dalam bentuk apapun sehubungan dengan pekerjaan atau jabatan, jasa, dan kegiatan yang dilakukan oleh Wajib Pajak orang dalam negeri”. Berdasarkan pengertian di atas, maka dapat disimpulkan bahwa Pajak penghasilan pasal 21 adalah pajak atas penghasilan berupa gaji, upah, honorarium, tunjangan, dan pembayaran lain dengan nama dan dalam bentuk apa pun sehubungan dengan pekerjaan atau jabatan, jasa, dan kegiatan yang dilakukan oleh orang pribadi. 


\section{METODE}

\section{Pendekatan Penelitian}

Pendekatan yang digunakan dalam penelitian ini adalah pendekatan kuantitatif dengan ilmiah yaitu berfikit untuk memecahkan masalah secara sistematis, empiris, dan terkontrol yang dengan angka-angka. Penelitian ini dilakukan di Kantor Pelayanan Pajak Pratama Makassar Selatan yang beralamat di jalan Urip Sumoharjo Km.4 GKN I Lt.1 Makassar. Adapun jenis data yang digunakan dalam penelitian ini adalah data kualitatif dan kuantitatof, sedangkan Sumber data yang diperoleh dalam penelitian ini adalah sumber primer dan sekunder.

\section{Metode Analisis Data}

Adapun metode analisis data yang digunakan untuk menguji hipotesis adalah menggunakan analisis regresi dengan bantuan perangkat lunak SPSS. Setelah data-data terkumpul, maka langkah selanjutnya dilakukan analisis data terdiri dari uji deskriptife statistic, uji kualitas data, uji asumsi klasik dan uji hipotesis. Pengujian hipotesis dilakukan dengan menggunakan persamaan regresi bergenda, uji t, uji determinasi, dan uji statistik F.

\section{HASIL DAN PEMBAHASAN}

\section{Penerimaa Pajak}

Kantor Pelayanana Pajak Pratama Makassar Selatan melayani daerahdaerah yang memiliki efektivitas perekenomian cukup tinggi terutama di Kecamatan Panakkukkang, Makassar dan Rappocini. Berikut ini Data Penerimaan Pajak Kantor Pelayanana Pajak Pratama Makassar Selatan (waktu 2014-2016)

Tabel 1. Penerimaan Pajak Kantor Pelayanana Pajak Pratama Makassar Selatan (waktu 2014-2016)

\begin{tabular}{llll}
\hline Tahun & Target & Realisasi & Efektivitas \\
\hline $\mathbf{2 0 1 4}$ & $867,734,835,000$ & $770,599,624,553$ & $89 \%$ \\
$\mathbf{2 0 1 5}$ & $1,209,200,027,964$ & $1,115,702,971,890$ & $96 \%$ \\
$\mathbf{2 0 1 6}$ & $1,691,549,999,999$ & $1,260,489,083,499$ & $75 \%$ \\
\hline
\end{tabular}

Efektivitas penerimaan paja pada Kantor Pelayanana Pajak Pratama Makassar Selatan berada pada angka $75 \%$ - $96 \%$. Berikut ini penerimaan pajak PPh Pasal 21 dan PPN.

Tabel 2. PPh. Pasal 21

\begin{tabular}{llll}
\hline Tahun & Target & Realisasi & Efektivitas \\
\hline 2014 & $119,164,157,000$ & $150,602,731,857$ & $126 \%$ \\
2015 & $153,393,396,000$ & $169,075,435,216$ & $110 \%$ \\
2016 & $194,033,327,000$ & $165,419,876,737$ & $85 \%$ \\
\hline
\end{tabular}

Analisis dan Hasil SPSS

\section{Asumsi Klasik}

Uji asumsi klasik ini terdiri atas uji normalitas data, uji heterokedastisitas dan uji multikolinearilitas.

\section{Uji Heterokedastisitas}

Tabel 3. Uji Heterokedastisitas

\begin{tabular}{llll} 
Model R R Square & $\begin{array}{l}\text { Adjusted } \\
\text { R Square }\end{array}$ & $\begin{array}{l}\text { Std. Error of the } \\
\text { Estimate }\end{array}$ \\
\hline $1 \quad .000^{\mathrm{a}} .000$ &.-043 & 38042061371 \\
\hline
\end{tabular}

a. Predictors: (Constant), X1, X2A, X2B, X3C

b. Dependent Variable: $\mathrm{Y}$
Berdasarkan pengujian di atas, maka dapat dilihat bahwa data tersebut bersifat residual yang lazim disebut homokedastisitas, terlihat pada besarnya pengaruh dari seluruh variabel independen terhadap variabel dependen. Pengaruh tersebut disimbolkan dengan $\mathrm{R}$ (korelasi) nilai pada kolom $\mathrm{R}$ adalah 0,000 artinya pengaruh variabel $\mathrm{PPh}$ Pasal 21 dan PPN terhadap penerimaan pajak adalah sebesar $0 \%$ $(0,000 \times 100 \%)$, kemudian terdapat nilai $\mathrm{R}$ Square sebesar $0 \%(0,000 \times 100 \%)$ pengaruh variabel independen terhadap variabel dependen, pada kolom selanjutnya terdapat nilai keakuratan model agresi atau Standard Error of The Estimate dimana tertera angka 38042061371856190000000.00000 .

Kesimpulan pada hasil diatas bahwa tidak terjadinya perbedaan varians dari residual suatu pengamatan ke pengamatan lain yang 
menunjukkan bahwa tidak terjadi Uji normalitas dilakukan untuk melihat heterokedastisitas. apakah dalam model regresi variabel terikat dan variabel bebas keduanya mempunyai distribusi

Uji Normalitas normal atau tidak.

Tabel 4. Uji Normalitas

\begin{tabular}{ll}
\hline & Unstandardized Residual \\
\hline $\mathrm{N}$ & 135 \\
\hline Mean & -0000322 \\
\hline NormatParameter a,b & 1517384351 \\
\hline Std. & 56030000 \\
\hline Deviation Absolute & .086 \\
\hline Most Extreme Differences Positive & .086 \\
\hline Negative & .055 \\
\hline Kolmogorov-Smimov Z & 1.022 \\
\hline Asymp. Sig (2-tailed) & .0247 \\
\hline
\end{tabular}

a. Test Distribution is Normal

b. Calculated from data

Tabel 5. Uji multikolinearitas

\begin{tabular}{|c|c|c|c|c|c|c|c|}
\hline \multirow{3}{*}{$\begin{array}{c}\text { Model } 1 \\
\text { (Constant) }\end{array}$} & \multicolumn{5}{|c|}{ Coefficients $^{\mathrm{a}}$} & \multirow{2}{*}{\multicolumn{2}{|c|}{ CollinearityStatistics }} \\
\hline & \multicolumn{2}{|c|}{ Unstandardized Coefficients } & \multirow{2}{*}{$\begin{array}{c}\text { Standardized } \\
\text { Coefficients }\end{array}$} & \multirow{2}{*}{$\mathrm{t}$} & \multirow{2}{*}{ Sig. } & & \\
\hline & B & Std. Error & & & & Tolerance & VIF \\
\hline \multirow[t]{2}{*}{$\mathrm{X} 1$} & 132302649962.568 & 28529847521.255 & & 4.637 & .001 & & \\
\hline & .189 & .180 & .724 & 1.050 & .000 & 329 & 3.041 \\
\hline
\end{tabular}

Berdasarkan di atas menunjukkan bahwa nilai toleransi pada uji multikolinearitas memenuhi nilain toleransi sebesar 0,10 .

\section{Uji Regresi Linear Berganda}

Regresi linear berganda digunakan untuk menguji pengaruh lebih dari satu independent variable terhadap dependen variable, regresi linear berganda untuk mengetahui hubungan fungsional antara beberapa variabel bebas (independent) secara bersama-sama terhadap variabel terikat (dependen) (Y).

Tabel. 6. Uji Regresi Linear Berganda

\begin{tabular}{|c|c|c|c|c|c|c|c|}
\hline & & & oefficients ${ }^{a}$ & & & & \\
\hline \multirow[t]{3}{*}{$\begin{array}{c}\text { Model } \\
1 \text { (Constant) }\end{array}$} & & $\begin{array}{l}\text { ardized } \\
\text { ients }\end{array}$ & $\begin{array}{l}\text { Standardized } \\
\text { Coefficients }\end{array}$ & \multirow[t]{2}{*}{$\mathrm{t}$} & \multirow[t]{2}{*}{ Sig. } & \multicolumn{2}{|c|}{$\begin{array}{c}\text { Collinearity } \\
\text { Statistics }\end{array}$} \\
\hline & $\mathrm{B}$ & Std. Error & Beta & & & Tolerance & VIF \\
\hline & .189 & .180 & .724 & 1.050 & .000 & 329 & 3.041 \\
\hline X1 PPh & .724 & .524 & .049 & 1.028 & .000 & 347 & 3.498 \\
\hline
\end{tabular}

a. Dependent Variable: $\mathrm{Y}$

$\mathrm{Y}=0,189+0,724 \mathrm{X}$

Dalam persamaan regresi linear berganda di atas dapat dijelaskan secara rinci:

a. Konstanta sebesar 0,189 hal ini berarti tidak terdapat perubahan variabel antara $\mathrm{PPh}$ Pasal 21 dan PPN terhadap Penerimaan Pajak Pada Kantor Pelayanan Pajak Pratama Makassar Selatan.

b. Nilai koefisien regresi untuk variabel $\mathrm{PPh}$ Pasal 21 sebrsar 0,724. Dalam penelitian ini dapat dinyatakan bahwa variabel $\mathrm{PPh}$ Pasal 21 (X1) berpengaruh positif terhadap
Penerimaan Pajak (Y), hal ini menunjukkan bahwa ketika $\mathrm{PPh}$ Pasal 21 meningkat sebesar satuan, maka Penerimaan Pajak akan mnegalami peningkatan sebesar 0,724 .

\section{Uji Hipotesis}

Uji Hipotesis adalah pernyataan yang didefinisikan dengan baik mengenai karakteristik populasi. Pengujian hipotesis yang digunakan dalam penelitian ini adalah uji $\mathrm{t}$ 
(parsial), uji F (simultan), dan uji determinasi. a. Uji parsial (t-test)

Uji parsial digunakan untuk mengetahui apakah variabel independen $(\mathrm{X})$ berpengaruh terhadap variabel dependen (Y). Pengujian dilakukan dengan taraf signifikan 0,05 . Jika ${ }^{t}{ }_{\text {hitung }}>\mathrm{t}$ tabel, maka $\mathrm{H}_{0}$ ditolak dan Ha diterima.

Sebaliknya Jika - ${ }_{\text {hitung }}^{\mathrm{t}}$ tabel, maka $\mathrm{H}_{0}$ diterima dan Ha ditolak.

Tabel 7. Uji Regresi Linear Berganda

Coefficients $^{\mathrm{a}}$

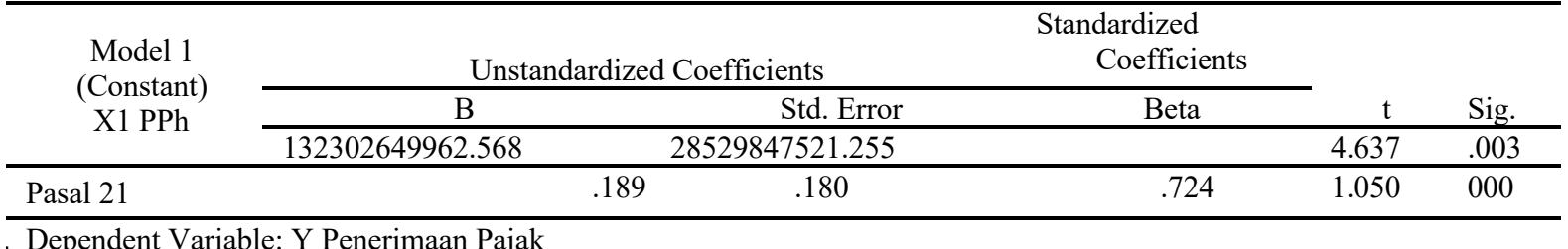

Berdasarkan tabel di atas menunjukkan bahwa variabel $\mathrm{PPh}$ Pasal 21 berpengaruh signifikan terhadap penerimaan pajak pada Kantor Pelayanan Pajak Pratama Makassar Selatan. Hal ini dibuktikan dengan tingkat signifikansi yang diperoleh dari variabel independen dibawah 0,05. Berdasarkan hasil uji parsial telah dilakukan antara variabel $\mathrm{PPh}$ Pasal 21 X1 terhadap Penerimaan Pajak pada Kantor Pelayanan Pajak Pratama Makassar Selatan variabel $\mathrm{Y}$ menunjukkan ${ }^{\mathrm{t}}$ hitung sebesar 1.050 dengan tingkat signifikansi sebesar 0,000 . Hasil ${ }^{\mathrm{t}}{ }_{\text {hitung }}$ tersebut jika dibandingkan dengan ${ }^{\mathrm{t}}$ tabel pada tingkat signifikansi $(\alpha=0,05)$. Diketahui bahwa ${ }^{t}$ hitung yang dihasilkan sebesar 1.050 lebih besar dari ${ }^{\mathrm{t}}$ tabel pada tingkat signifikansi $(\alpha=0,05)$. Berarti
$\mathrm{H}_{0}$ ditolak dan Ha diterima. Dengan demikian dapat disimpulkan bahwa variabel PPh Pasal 21 berpengaruh secara signifikan terhadap Penerimaan Pajak Pada Kantor Pelayanan Pajak Pratama Makassar Selatan.

\section{Uji simultan (F-test)}

Untuk mengetahui secara bersama-sama apakah simultan variabel bebas $\mathrm{X}_{1}, \mathrm{X}_{2}$ memiliki hubungan yang signifikan dengan variabel dependen (Y), maka dapat dilakukan uji signifikan dengan hipotesa. Pengujian dilakukan dengan taraf signifikansi sebesar 0,005 . Apabila $\mathrm{F}_{\text {hitung }}>\mathrm{F}$ tabel, maka $\mathrm{H}_{0}$ ditolak dan Ha diterima. Jika - Fhitung $<$ Ftabel, maka $\mathrm{H} 0$ diterima dan Ha ditolak.

\section{PPh21}

Tabel 8. Uji simultan (F-test)

\begin{tabular}{|c|c|c|c|c|c|}
\hline ANOVA \\
\begin{tabular}{|c|c|c|c|c|c|}
\hline Model & Sum of Squares & df & Mean Square & F & Sig. \\
\hline 1 Regression & 10036984093154370000.000 & 1 & 100369840936154370000.000 & 1.103 & $.000^{\text {a }}$ \\
\hline Residual & 91014046386432740000.000 & 1 & 91014046386432740000.000 & & \\
\hline Total & 191383887322587 & & & & \\
\hline & 100000.000 & 2 & & & \\
\hline
\end{tabular}
\end{tabular}

a. Predictors: (Constant), X1

b. Dependent Variable: $\mathrm{Y}$

Berdasarkan uji $\mathrm{F}$, didapat - ${ }^{\mathrm{F}}$ hitung sebesar 1.103 dengan tingkat signifikansi sebesar 0,000 . Nilai probabilitas $(0,000)$ lebih kecil dari 0,005 maka model regresi dapat dipakai untuk memeprediksi penerimaan pajak pada Kantor Pelayanan Pajak Makassar Selatan. Hasil ${ }_{\text {hitung }}$ tersebut jika dibandingkan dengan ${ }^{\mathrm{F}}$ tabel pada tingkat keyakinan $95 \%(\alpha=0,05)$. Diketahui bahwa $\mathrm{F}_{\text {hitung yang dihasilkan sebesar 1.103, lebih besar }}$ dari ${ }_{\text {tabel }}$ pada tingkat signifikansi sebesar 0,005 yaitu 0,000 . Ini berarti $\mathrm{H}_{0}$ ditolak dan $\mathrm{Ha}$ diterima. Hal ini menunjukkan bahwa variabel $\mathrm{PPh}$ Pasal 21 berpengaruh secara simultan terhadap Penerimaan Pajak Pada Kantor Pelayanan Pajak Pratama Makassar Selatan.

\section{Koefisien Determinasi $\left(\mathbf{R}_{\mathbf{2}}\right)$}

Koefisien determinasi bertujuan untuk mengetahui persentasi besarnya pengaruh variabel bebas terhadap variabel terikat. Koefisien determinasi pada dasarnya mengukur seberapa jauh kemampuan model dalam 
menerangkan variasi variabel dependen. Artinya semakin besar nilai $\mathrm{R}_{2}$ maka akan semakin baik model regresi dengan data yang ada, sehingga semakin tepat model ini bisa digunakan untuk menjelaskan variabel dependen oleh variabel independen.

Tabel 4.13. PPh21

Model Summary ${ }^{\mathrm{b}}$

\begin{tabular}{lllll}
\hline Model & R & R Square & $\begin{array}{l}\text { Adjusted } \\
\text { R Square }\end{array}$ & Std. Error of the Estimate \\
\hline 1 & $.724^{\mathrm{a}}$ & .524 & .049 & $8,430,133.43031$
\end{tabular}

a. Predictors: (Constant), X1

b. Dependent Variable: Y

Berdasarkan hasil uji koefisien determinasi di atas, nilai pada Adjusted $\mathrm{R}$ yang dapat diartikan sebagai pengaruh variabel independen terhadap variabel dependen diperoleh nilai sebesar 0,049, sedangkan nilai pada $\mathrm{R}$ Square sebesar 0,524 , dan nilai $\mathrm{R}$ atau korelasi pada tabel di atas adalah sebesar 0,724 .

\section{KESIMPULAN DAN SARAN}

\section{Kesimpulan}

Berdasarkan hasil analisis data yang telah diuraikan secara rinci pada bab sebelumnya, maka dapat disimpulkan sebagai berikut. Berdasarkan hasil uji parsial, menunjukkan bahwa variabel $\mathrm{PPh}$ Pasal 21 berpengaruh terhadap Penerimaan Pajak Pada Kantor Pelayanan Pajak Pratama Makassar Selatan, dengan presentasi penerimaan pajak sebesar $72,4 \%$.

\section{Saran}

Berdasarkan Penelitian yang telah dilakukan menunjukkan bahwa semua variabel yang telah diuji secara parsial dan simultan berpengaruh. Kantor Pelayanan Pajak Pratama Makassar Selatan diharapkan dapat memperhatikan dan memahami pengaruh $\mathrm{PPh}$ Pasal 21 dan PPN (Pendapatan Dalam Negeri, Import, Lainnya) terhadap Penerimaan Pajak Pada Kantor Pelayanan Pajak Pratama Makassar Selatan,setiap tahun dapat diperoleh angka peningkatan yang lebih signifikan sehingga dapat menambah Penerimaan Pajak, terlebih untuk PPh Pasal 21 dengan presentase sebesar $72,4 \%$ lebih rendah dibandingkan dengan presentase sebesar 90,2\% yang hampir mencapai $100 \%$ pada sumbangsi Penerimaan Pajak pada Kantor Pelayanan Pajak Pratama Makassar Selatan.

\section{REFERENSI}

Arnold, J Brian dan Michael J Mclntyre., 2006. International Tax Primer. Second Edition, New York, Kluwer.

Abdul, Kosasih dan Eva, 2012. Analisis Sistem Pajak BPHTB Dari Pajak Pusat Menjadi Pajak Daerah Terhadap PAD Kabupaten Karawang, Jurnal Perpajakan., vol. 11. NO. 24. Edisi Sep-Nov 2012. Universitas Singaperbangsa. Karawang.

Budiman dan Setiyono, 2012. Dasar-dasar pajak, Jakarta: Fajar

Damayanti, 2005. Perpajakan Indonesia: Mekanisme Perhitungan Perpajakan. Jakarta: Yayasan Obor Indonesia

Devano,Sony,.Siti.Kurnia.Rahayu..2006..Perpa jakan:Konsep,. Teori,.Isu. Jakarta: Kencana.

Evi.2012. Implementasi Tax Planning terhadap Perhitungan PPh Badan pada PT.PELNI $I V$. Makassar: Skripsi Program Sarjana Fakultas Ekonomi Universitas Hasanuddin..Makassar.

Hadi.2008. Pengaruh PPh Final Dan BPHTB Terhadap permohonan hak baru atas tanah dan bangunan yang belum bersertifikat dan setelah bersertifikat di Kota Binjai. Jurnal Pajak. Binjai.

Hartati. 2015. Pengantar Perpajakan. Bandung: Pustaka Setia.

Imam. 2013. Penerapan Perencanaan Pajak Penghasilan Pasal 21 Sebagai Strategi Penghematan Pembayaran Pajak Perusahaan. Jember: Skripsi Program Sarjana Fakultas Ekonomi Universitas Jember.

Leonardo R.Watung. Analisis Penerapan Pajak dengan withholding Tax Sistem terhadap Pajak Penghasilan Pasal 4 ayat 2 pada 
PT.BANK SULUTGO di Kota Manado. Jurnal Emba. vol.4, .No.1, Hal 916-923. Fakultas Ekonomi dan Bisnis..Universitas Sam Ratulangi. .Manado.

Melita. Pelaksanaan Peralihan dan Pendaftaran Peralihan Hak Milik Atas Tanah (Jual Beli) Dalam Mewujudkan Tertib Administrasi Pertanahan di Kabupaten Toraja Utara. .Jurnal Pajak.Fakultas Hukum. .Universitas Atma Jaya Yogyakarta. Yogyakarta.

Muhammad Rachmat Putra. 2011. Analisis Pengaruh Pemungutan PPh Final Atas Pengalihan Hak Atas Tanah dan Bangunan. Surabaya: Skripsi Program Sarjana Fakultas Ekonomi Universitas Airlangga Surabaya. Madiasmo. 2009. Perpajakan. Edisi Revisi. Yogyakarta: Andi.

Meliala, Tuli. 2012. Perpajakan dan Akuntansi Perpajakan. Jakarta: Semesta Media.

Nasucha, Chaizi. 2005. Revisi Administrasi Publik. Jakarta: Grasindo.

Rahayu, Siti Kurnia. 2010. Perpajakan Indonesia Konsep dan Aspek Formal. Yogyakarta: Graha Ilmu.

Suandy. Erly. 2008. Perencanaan Pajak. Edisi Keempat. Jakarta: Salemba Empat. 2011. Hukum Pajak.Edisi Keempat. Jakarta: Salemba Empat.

Soemitro. Rochmat. 2012. Dasar-dasar Hukum Pajak dan Pajak

Pendapatan. Bandung: Eresco

Sri. 2016. Analisis Penagihan Aktif Sanksi Perpajakan Terhadap Kepatuhan Wajib Pajak Dan Implikasinya Pada Penerimaan Pajak Pada Kantor Pelayanan Pajak Pratama Makassar Selatan. Makassar: Skripsi Program Sarjana Fakultas Ekonomi Universitas Hasanuddin Makassar.

Waluyo, 2008. Akuntansi Perpajakan. Jakarta: Salemba Empat.
2011. Akuntansi Perpajakan. Edisi 2. Jakarta: Salemba Empat.

Wijaya, Tony. 2012. Cepat Menguasai SPSS 20 untuk Olah dan Interpretasi Data. Yogyakarta: Cahaya Atma Pustaka.

www.pajak.go.id (diakses 2 Juli 2017)

Anonim. Undang-Undang Nomor 6 Tahun 1983 Tentang Pajak Penghasilan.

Anonim. Undang-Undang Nomor 7 Tahun 1983 Tentang Pajak Penghasilan.

Anonim. Undang-Undang Nomor 8 Tahun 1983 Tentang Pajak Pertambahan Nilai Barang dan Jasa dan Pajak Penjualan Atas Barang Mewah.

Anonim. Undang-Undang Nomor 11 Tahun 1994 tentang Perubahan Atas UndangUndang Nomor 8 Tahun 1983 Tentang Pajak Pertambahan Nilai Barang dan Jasa dan Pajak Penjualan Atas Barang Mewah

Anonim. Undang-Undang Nomor 17 Tahun 2000 tentang Perubahan kedua atas Undang-Undang Nomor 8 Tahun 1983 Tentang Pajak Pertambahan Nilai Barang dan Jasa dan Pajak Penjualan Atas Barang Mewah.

Anonim. Undang-Undang Nomor 19 Tahun 2000 tentang Perubahan kedua atas Undang-Undang RI Nomor 19 Tahun 1997 Tentang Penagihan Pajak dengan Surat Paksa.

Anonim. Peraturan Direktur Jenderal Pajak Nomor PER-159/PJ/2006 Tentang Saat Pembuatan, Bentuk, Ukuran, Pengadaan, Tata Cara Penyampaian, dan Tata Cara Pembetulan Faktur Pajak Standar Surat Edaran Dirjen Pajak No. SE13/PJ.52/2006 Tanggal: 31-10-2006.

Anonim. Undang-Undang Nomor 16 Tahun 2009 tentang Ketentuan Umum dan Tata Cara Perpajakan (UU KUP). 